\title{
PECULIARITIES OF INTERNATIONAL AND NATIONAL EXPERIENCE OF PREVENTION OF CONFLICT OF INTEREST SETTLEMENT
}

The purpose of the article is to analyze international and domestic regulations governing the activities related to the prevention and settlement of conflicts of interest, identify shortcomings in the legislation in this area and provide proposals for their elimination.

Methods. The study used methods of analysis and synthesis to determine methods of constructive conflict of interest settlement, as well as to study the international experience of conflict of interest settlement in the civil service. Statistical and graphical methods are used to analyze the current state of conflict of interest. Modeling and forecasting to develop proposals to improve the procedure for preventing and resolving conflicts of interest. Results. The normative-legal acts of the national and international legislation, which regulate the activity in the direction of prevention and settlement of the conflict of interests, are analyzed. The main normative act of international law has been found to be the 2003 UN Convention against Corruption. In domestic legislation, the concept of "conflict of interest" was first enshrined in the Law of Ukraine "On Principles of Preventing and Combating Corruption" in 2011. It is most often studied as an element of the mechanism to prevent abuse of state power or as a principle of integrity of state power. It is determined that in the national legislation the conflict of interests is divided into potential and real, in the international legislative practice into obvious and potential. The main signs and causes of conflict of interest as a type of corruption-related offense are highlighted. It is stated that conflicts of interest and corruption cannot be considered in direct connection. Transparency International's statistics on the Corruption Perceptions Index 2020, the report of the National Agency for the Prevention of Corruption for 2020 were studied, and it was substantiated that in Ukraine, despite anti-corruption reform, the overall level of corruption remains high.

It is theoretically substantiated that the main mechanism for resolving a conflict of interest is its legal regulation at the level of law. The main directions for preventing and counteracting conflicts of interest are outlined. The positive experience of resolving conflicts of interest in the civil service in Germany and France is considered, whose anti-corruption policy is mainly aimed not at resolving conflicts of interest, but at preventing their occurrence. It is stated that in international practice there are three models of conflict of interest settlement: preventive, "difficult way", compliance-based.

Conclusions. It is concluded that counteracting the negative manifestations of conflicts of interest is possible only by defining the order of actions of civil servants in which it arose and by defining a clear mechanism for resolving conflicts. Proposals for amendments to the Law of Ukraine "On Prevention of Corruption" and the Code of Ukraine on Administrative Offenses were submitted.

Key words: anti-corruption policy, normative legal acts, international practice, state powers, counteraction of conflict of interests, settlement mechanism.

JEL Classification: K10 General; K19 Other.

\section{Oksana LEHKA,}

Professor at the Department of International Law

University of Customs and Finance,

Doctor of Law, Professor

ok.legka@gmail.com

orcid.org/0000-0002-7589-5908

\section{Aivars Vilnis KRASTINS,} Head of Department of Customs and Taxes

Riga Technical University, professor Dr. oec.,

Director of International Business and Customs Institute,

Aivars.Krastins@rtu.Iv

\section{Introduction}

The legislative and reform processes currently taking place in Ukraine are primarily aimed at overcoming corruption, the most negative phenomenon that stands in the way of building an economically viable and self-sufficient state. At all the times corruption exert destructive influence to all spheres of public life acting as a crisis phenomenon that erodes the entire state apparatus from within and manifests itself in criminal and administrative offenses (Drozd, Titko, 2014). In Ukraine, despite anti-corruption reform, general level of corruption remains high this is negatively perceived by society and requires decisive action. Thus, according to the Transparency International Corruption Perceptions Index, in 2020 Ukraine ranked 117th among 180 countries (Transparency 
International Ukraine, 2021). The level of legal regulation of the sphere of conflict of interests in public law relations is also insufficient. Thus, among the people's deputies of Ukraine $9 \%$ have signs of conflict of interest, and this directly affects the objectivity, fairness and completeness of the person's state power, and therefore there is a need for regulation of precautionary measures or their resolution in favor of interests of society (Yurchyshyn, Poltavets, 2017; Bytiak, 2005).

\section{Analysis of recent research and publications}

The issue of conflict of interest was addressed in research of following scientists Yu.P. Bytiak, T.E. Vasylevska, V.I. Vasylynchuk, N.H. Dekhanova, V.K. Kolpakov, I.P. Lopushynskyi, V.Ya. Malynovskyi, O.Y. Obolenskyi, O.M. Oleshko, I.D. Pastukh, M.I. Rudakevych, Y.O. Kholodenko and others. Among foreign practitioners who have studied this area, noteworthy are the studies of David Arellano-Gault, Laura Zamudio-Gonzalez, Walter Lepore.

The purpose of the article is an analysis of international and domestic normative-legal acts, which regulate activity in the part concerning prevention and settlement of conflict of interests, revealing of imperfections of the legislation in this direction and granting of offers on their elimination.

\section{Presenting of main material}

In order to form an understanding of the content of the institution of prevention and settlement of conflicts of interest, it is necessary to analyze the regulations of national and international law governing activities in this area. The main normative act of international law in this direction is the UN Convention against Corruption, adopted by General Assembly resolution 58/4 of October 31, 2003 and ratified by the Law of Ukraine of October 18, 2006 № 251-V (entered into force only on January 1, 2010), which provides: " $<\ldots>$ Each State Party seeks to create, maintain and strengthen systems that promote transparency and prevent conflicts of interest; introduce measures and systems that oblige public officials to provide the relevant bodies with declarations of extracurricular activities, occupations, investments, assets and significant gifts and profits, which may result in a conflict of interest regarding their functions as public officials" (United Nations, 2007).

The basic principles of prevention and settlement of conflicts of interest are set out in the International Code of Conduct for Public Officials, adopted by Ukraine on July 23, 1996. In particular, it is stipulated that civil servants do not use their official position for unjustified personal gain or personal and financial benefit for their families. They do not perform any functions and do not have any financial, commercial or other interests that are incompatible with their position, functions, responsibilities (United Nations, 1996).

In domestic law, the concept of "conflict of interest" was first enshrined in 2011 in the Law of Ukraine "On Principles of Prevention and Combating Corruption" (in 2016 it expired due to the adoption of the Law of Ukraine "On Prevention of Corruption", which, incidentally, definition of the definition of "conflict of interest" is missing). According to this document, a conflict of interest - is contradiction between personal property interest, intangible interest of person or people close to her and official authority, the existence of which may affect the objectivity or impartiality of decision-making, as well as the commission or omission of actions in the exercise of official powers (Article 1 of Section 1) (Verkhovna Rada of Ukraine, 2011). It is most often studied as an element of the mechanism to prevent abuse of state power or as a principle of integrity of state power. Conflicts of interest are divided into potential (having a private interest in the field in which he performs his official or representative powers) and real (conflict between the private interest of the person and his official or representative powers) (Verkhovna Rada of Ukraine, 2014).

The National Agency for Prevention of Corruption monitors and controls the implementation of legislation on ethical conduct, prevention and settlement of conflicts of interest in the activities of persons authorized to perform state or local government functions and persons equated to them.

According to the National Agency for the Prevention of Corruption (2020 report), the Department for Compliance with Conflicts of Interest and Restrictions on the Prevention of Corruption in 2020 issued 31 injunctions for violations of the law on ethical conduct, prevention and settlement of conflicts of interest, other requirements and restrictions provided by the Law, and 95 requests were sent to identify and/or resolve conflicts of interest (National Agency for the Prevention of Corruption, 2021).

In addition, 239 protocols on administrative offenses were drawn up: Part 1 of Art. 172-4 of the Code of Administrative Offenses (violation of restrictions on engaging in other paid activities or business); Part 2 of Art. 172-4 of the Code of Administrative Offenses (violation of restrictions on membership in the board, other executive or control bodies, etc.); Part 1 of Art. 172-5 of the Code of Administrative Offenses (violation of restrictions on receiving gifts); Part 1 of Art. 172-7 of the Code of Administrative 
Offenses (failure to report the existence of a real conflict of interest); Part 2 of Art. 172-7 of the Code of Administrative Offenses (taking actions or making decisions in conditions of real conflict of interest); Art. 188-46 of the Code of Administrative Offenses (failure to comply with legal requirements (instructions) of the NAPC) (see fig. 1).

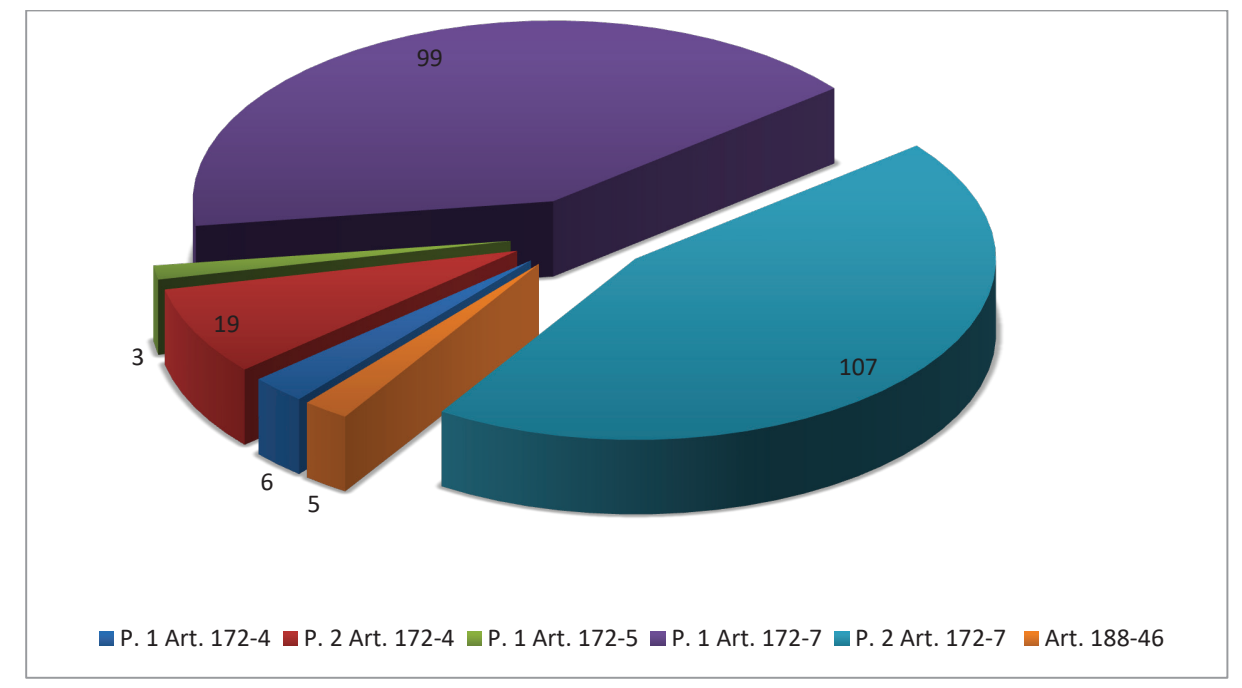

Figure. 1. Protocols on administrative offenses related to conflicts of interest

Signs of conflict of interest as a type of corruption-related offense include: violation of the requirements, prohibitions and restrictions provided by the Law of Ukraine "On Prevention of Corruption"; committed by persons authorized to perform the functions of the state or local self-government and persons equated to persons authorized to perform the functions of the state or local self-government.

In international legal practice, the definition of "conflict of interest" proposed by the OECD Recommendations is common, according to which a conflict of interest is a conflict between public law obligations and the private interests of a public official, in which the public official's interest is related to private opportunities of individuals may adversely affect their performance of their duties and functions (OECD, 2021). It should be noted that according to these recommendations, there is an obvious (there is a personal interest that affects the performance of public officials, even if such a negative impact does not actually have) and a potential conflict of interest.

Among main reasons of the emergence of private interests and, as a consequence, conflicts of interest distinguish: distorted moral level of civil servants; creation of such conditions under which a civil servant has a situation that may lead to a conflict of interest; imperfection of the mechanism for preventing conflicts of interest; lack of an effective mechanism for criminal and administrative prosecution.

We need to pay attention at the fact that existence of conflict of interest doesn't indicate direct corruption component that a person independently decides what to do in a given situation, the arbiter here is the morality of man. That is why we cannot consider conflicts of interest and corruption in direct relation.

However, although conflicts of interest cannot be equated with corruption, in most cases corruption arises when the private interest affects or may affect the performance of the duties of civil servants, indicating that the conflict between private interests and obligations of civil servants can be a source of corruption. The scientific approach of K.L. Buhaichuk and O.I. Bezpalova deserves attention, according to whom "conflict of interest can occur not only when the conflict has actually affected the objectivity and impartiality of decision-making (whether or not to act), but also when it can potentially affect them" (Buhaichuk, Bezpalova, 2016).

In international regulations, the definition of "conflict of interest" is defined in Section 2 of the International Code of Conduct for Civil Servants (UN), Article 13 of the Model Code of Conduct for Civil Servants of the Committee of Ministers of the Council of Europe, Guidelines for Organizing Economic Cooperation and Development, ethical and anti-corruption codes of conduct of public services. It should be noted that the Model Code of Conduct for Civil Servants is an appendix to Recommendation 
№ R (2000) of the Committee of Ministers to member states of the Council of Europe on codes of conduct for civil servants, and based on this code developed the vast majority of codes of ethics for civil servants.

Main mechanism of settlement of conflict of interest is its legal regulation at the level of law. In particular, conflict of interest in Poland is settled by norms of legislation on public service (TokarOstapenko, 2013). It should be noted that Polish conflict of interest doesn't connect with corruption and this is the main reason that the legal system put in place is not fully applied; in Bulgaria, Latvia, Lithuania by the norms of the legislation on the conflict of interests (Council of the Baltic Sea States, 2008); in Slovenia and Estonia, on the prevention of corruption (Kovryzhenko, 2011).

Criminal law, public administration law, civil service, and ethics of conflict of interest in the United States (Raile, 2004), codes of conduct in Korea, public service law in Hong Kong and Singapore in Asia and the Pacific (OECD, 2003). The outlined legislative acts provide mechanism of settlement of conflict of interest which covers different in essence, but interconnected in content tools aimed at preventing, preventing, overcoming conflicts of interest in public authorities.

In international practice distinguish three models of settlement conflict of interest: first - preventive model (conflicts of interest are settled by instruments on a residual basis; there is almost no systemic corruption, and the settlement covers the best practical tools for prevention, prevention, overcoming conflicts of interest - Germany, France, Switzerland, EU countries) (Rivchachenko, 2015); second - "the hard way" (settlement of conflict of interest which is based on moral requirements of the employee, provided by the recommended codes of ethics - Australia, Canada, USA). It should be noted that the issue of conflict of interest becomes relevant in the US Congress. In particular, according to the Harvard Business Review, the number of members of Congress who own shares tends to increase. Members of the House of Representatives and the Senate generate an abnormally high return on their investment. According to foreign jurists, this is due to a number of tools available to parliamentarians: from pushing or "burying" legislative initiatives to regulating contracts, subsidies and tax rebates (Yurchyshyn, Poltavets, 2017; Rivchachenko, 2015); third - compliance-based (acts according to the principles established by the code of rules of conduct, is fixed by normative legal acts of direct action; where the key areas for resolving conflicts of interest are nepotism, patronage, gifts, use of official information in selfish interests - Japan, Singapore, Hong Kong, South Korea) (Rivchachenko, 2015).

Thus, among the main areas for preventing and combating conflicts of interest are: limiting of combination; declarations about personal income, income of family, personal property, presents; declaration of private interest which has related to contract management, decision-making, participation in the preparation or provision of policy recommendations; limiting and control after ending of labor activity of business or activities of non-governmental organizations, gifts and other forms of assistance, external revenues; refusal and procedure of removal of public officials from the performance of public duty with the participation of representatives of the parties or the adoption of a specific decision that may lead to a conflict of interest; alienation through the sale of business interests, investments or through the creation of trust or "blind trust" in management (Zibold, 2013).

Worth noting is the experience of settlement of conflict of interest at the Public Service of Germany, where principle of settlement $\mathrm{s}$ based of idea that every person who performs public functions, must inform about any personal interest, which may even approximately affect the decision of the official. In Germany that is important not only to prevent conflicts of interest in advance, but also to avoid even the appearance (assumption) of untruths (Petrova, 2015). As we can see, Germany's anti-corruption policy is not aimed primarily at resolving conflicts of interest, but at preventing them.

As for sanctions to those who violated the rules of conflict of interest policy, the most severe restrictions were introduced in France. Thus, the Criminal Code of the country provides for three groups of criminal acts of corruption: 1) abuse of power, acts that encroach on government; 2) abuse of power, acts that infringe on the rights of the individual; 3) violation of the duty of decency (Kabashov, 2021). In addition criminal law of France contains a separate article for a crime involving a conflict of interest, which is "illegal promotion of interests". Charges under this article may be brought against any civil servant who commences employment with a company which has been under his control for the last 5 years of service, i. e. over which an official has supervised or supervised (Yurchyshyn, Poltavets, 2017). It should be noted that according to the Law of Ukraine "On Prevention of Corruption", the term of such a restriction is only 1 year. 


\section{Conclusions}

Thus, it is possible to counteract the negative manifestations of conflicts of interest only by defining the order of actions of civil servants in which it arose and by defining a clear mechanism for resolving conflicts (Pastukh, 2020). Positive international experience in this area shows that the management of conflicts of interest in the civil service takes place at the stages of conflict prevention, conflict detection and elimination of the negative consequences of the conflict. The basis in this direction is the well-established activities of: the legislature on the application of current and implementation of positive experience; executive power to ensure the organization of control and monitoring of anti-corruption bodies; the judiciary on the effectiveness of the anti-corruption court, the abolition of illegal decisions taken in the event of a conflict of interest, the improvement of law enforcement practices to resolve conflicts of interest through a system of judicial precedents.

In order to prevent and resolve conflicts of interest, it is advisable to make appropriate changes to current domestic legislation, in particular in the Law of Ukraine "On Prevention of Corruption": provide for the definition of "conflict of interest"; distinguish between corruption crimes and corruption-related offenses. In addition, the Law of Ukraine "On Prevention of Corruption" provides for administrative liability for violation of the deadlines for taking appropriate measures to resolve conflicts of interest, accordingly supplementing the Code of Administrative Offenses of Ukraine with the article "Violation of deadlines for conflict of interest”.

\section{References:}

1. Drozd, A.Yu., Titko, A.V. (2014). Sluzhba finansovykh rassledovaniy kak organ bor'by s administrativnymi korruptsionnymi pravonarusheniyami i ego zarubezhnye analogy [Financial Investigation Service as a body for combating administrative corruption offenses and its foreign counterparts]. Naukovyi visnyk Uzhhorodskoho natsionalnoho universytetu. Seriia "Pravo", no. 28(2), pp. 123-127 [in Russian].

2. Transparency International Ukraine (2021). Ukraina v Indeksi spryiniattia koruptsii-2020 [Ukraine in the Corruption Perception Index 2020]. Retrieved from: http://cpi.ti-ukraine.org [in Ukrainian].

3. Yurchyshyn, Ya., Poltavets, U. (2017). Propozytsii do polityky shchodo konfliktu interesiv narodnykh deputativ Ukrainy [Proposals for a policy on the conflict of interests of people's deputies of Ukraine]. Retrieved from: https://parlament.org.ua/wp-content/uploads/2017/09/Propozicii_Politiki_deklaruvannya_Konfliktu-1. pdf [in Ukrainian].

4. Bytiak, Yu.P. (2005). Derzhavna sluzhba v Ukraini: orhanizatsiino-pravovi zasady: monohrafiia [Civil service in Ukraine: organizational and legal principles: monograph]. Kharkiv: Pravo, 304 p. [in Ukrainian].

5. United Nations (2007). Konventsiia Orhanizatsii Obiednanykh Natsii proty koruptsii vid 31 zhovtnia 2003 roku [United Nations Convention against Corruption of 31 October 2003]. Vidomosti Verkhovnoi Rady Ukrainy, no. 49, pp. 2048 [in Ukrainian].

6. United Nations (1996). Mizhnarodnyi kodeks povedinky derzhavnykh posadovykh osib vid 23 lypnia 1996 roku [International Code of Conduct for Public Officials of July 23, 1996]. Retrieved from: https://zakon.rada.gov.ua/laws/show/995_788\#Text [in Ukrainian].

7. Verkhovna Rada of Ukraine (2011). Pro zasady zapobihannia i protydii koruptsii: Zakon Ukrainy vid 7 kvitnia 2011 roku № 3206-VI [On the Principles of Preventing and Combating Corruption: Law of Ukraine of April 7, 2011 № 3206-VI]. Retrieved from: http://zakon.rada.gov.ua/laws/show/3206-17 [in Ukrainian].

8. Verkhovna Rada of Ukraine (2014). Pro zapobihannia koruptsii: Zakon Ukrainy vid 14 zhovtnia 2014 roku № 1700-VII [On Prevention of Corruption: Law of Ukraine of October 14, 2014 № 1700-VII]. Retrieved from: http://zakon.rada.gov.ua/laws/show/1700-18 [in Ukrainian].

9. National Agency for the Prevention of Corruption (2021). Zvit za 2020 rik [Report for 2020]. Retrieved from: https://nazk.gov.ua/wp-content/uploads/2021/04/NAZK-Zvit-za-2020-rik-15.04.2021-1.pdf [in Ukrainian].

10. OECD (2021). Recommendation of the Council on OECD Guidelines for Managing Conflict of Interest in the Public Service. Retrieved from: https://legalinstruments.oecd.org/public/doc/130/130.en.pdf [in English].

11. Buhaichuk, K.L., Bezpalova, O.I. (2016). Zapobihannia konfliktu interesiv v diialnosti osib, upovnovazhenykh na vykonannia funktsii derzhavy ta mistsevoho samovriaduvannia: naukovo-metodychni rekomendatsii [Prevention of conflicts of interest in the activities of persons authorized to perform the functions of state and local self-government: scientific and methodological recommendations]. Kharkiv: Kharkiv National University of Internal Affairs, 41 p. [in Ukrainian].

12. Tokar-Ostapenko, O.V. (2013). Urehuliuvannia konfliktu interesiv na derzhavnii sluzhbi: mozhlyvosti zastosuvannia yevropeiskoho dosvidu v Ukraini: analitychna dopovid [Settlement of conflict of interest in the 
civil service: opportunities to apply the European experience in Ukraine: an analytical report]. Kyiv: National Institute for Strategic Studies, 48 p. [in Ukrainian].

13. Council of the Baltic Sea States (2008). Corruption prevention in public administration in the countries of the Baltic Sea Region (Presented at the 7th Baltic Sea States Summit in Riga, 2008). Retrieved from: http://providus.lv/upload_file/Publikacijas/Valsts_kvalitate/CBSS_revised_180608.pdf [in English].

14. Kovryzhenko, D.S. (2011). Zapobihannia konfliktu interesiv ta koruptsii v deputatskii diialnosti: dosvid krain YeS ta propozytsii dlia Ukrainy: informatsiino-analitychne doslidzhennia [Prevention of conflicts of interest and corruption in parliamentary activity: the experience of EU countries and proposals for Ukraine: information-analytical study]. Kyiv: Laboratory of Legislative Initiatives, 105 p. [in Ukrainian].

15. Raile, E. (2004). Managing Conflicts of Interest in the Americas: a comparative review. Retrieved from: https://www2.oge.gov/web/oge.nsf/0/536F309DDC9D8F96852585B6005A12BD/\$FILE/36d75c57a70847 3ca786a10c264797783.pdf [in English].

16. OECD (2003). Anti-korruptsionnaya politika v Azii i Tikhookeanskom regione: pravovaya i institutsional'naya osnova bor'by s korruptsiey v shestnadtsati stranakh Aziatskogo i Tikhookeanskogo regiona: predvaritel'nyy otchet [Anti-corruption policies in Asia and Pacific region: legal and institutional framework for fighting corruption in sixteen countries in Asia and the Pacific region: preliminary report]. Retrieved from: https://www.oecd.org/site/adboecdanti-corruptioninitiative/policyanalysis/35189187.pdf [in Russian].

17. Rivchachenko, S.V. (2015). Dosvid zarubizhnykh krain u sferi pravovoho rehuliuvannia zapobihannia ta vrehuliuvannia konfliktu interesiv [Experience of foreign countries in the field of legal regulation of prevention and settlement of conflicts of interest]. Naukovyi visnyk Khersonskoho derzhavnoho universytetu. Seriia "Yurydychni nauky", no. 3-2, vol. 4, pp. 181-187 [in Ukrainian].

18. Zibold, F. (2013). Conflicts of interest in public administration. Retrieved from: https://www.europarl. europa.eu/document/activities/cont/201302/20130221ATT61562/20130221ATT61562EN.pdf [in English].

19. Petrova, S.G. (2015). Konflikt interesov na gosudarstvennoy sluzhbe: opyt Rossii i zarubezhnykh stran [Conflict of interest in the civil service: experience of Russia and foreign countries]. Innovatsionnaya nauka, no. 6, pp. 201-203 [in Russian].

20. Kabashov, S.Yu.(2021). Uregulirovaniekonflikta interesov i protivodeystviekorruptsii na grazhdanskoy i munitsipal'noy sluzhbe: teoriya i praktika: uchebnoe posobie [Settlement of conflicts of interest and anticorruption in the civil and municipal service: theory and practice: a study guide]. Moscow: Infra-M, 192 p. [in Russian].

21. Pastukh, I.D. (2020). Zapobihannia ta vrehuliuvannia konfliktiv interesiv v diialnosti publichnoi administratsii: administratyvno-pravove doslidzhennia: monohrafiia [Prevention and settlement of conflicts of interest in the activities of public administration: administrative and legal research: monograph]. Kyiv: Vydavnychyi tsentr "Kafedra", 432 p. [in Ukrainian].

\title{
ОСОБЛИВОСТІ МІЖНАРОДНОГО Й НАЦІОНАЛЬНОГО ДОСВІДУ ВРЕГУЛЮВАННЯ КОНФЛІКТУ ІНТЕРЕСІВ ТА ЗАПОБІГАННЯ ЙОМУ
}

\author{
Оксана ЛЕГКА, \\ професор кафедри міжнародного права \\ Університету митної справи та фінансів, \\ доктор юридичних наук, професор \\ ok.legka@gmail.com \\ orcid.org/0000-0002-7589-5908 \\ Айварс Вільніс КРАСТІНС, \\ завідувач кафедри митної справи та податків \\ Ризького технічного університету, \\ доктор технічних наук, професор, \\ директор Міжнародного інституту бізнесу та митного управління \\ Aivars.Krastins@rtu.lv
}

\begin{abstract}
Метою статті є аналіз міжнародних та вітчизняних нормативно-правових актів, які регламентують діяльність щодо врегулювання конфлікту інтересів $і$ запобігання йому, виявлення недосконалостей законодавства в иьому напрямі та надання пропозищій щодо їх усунення.

Методи. У дослідженні з метою визначення методів конструктивного врегулювання конфлікту інтересів, а
\end{abstract}


також вивчення міжнародного досвіду врегулювання конфлікту інтересів на державній службі використано методи аналізу та синтезу. Статистичний і графічний методи застосовано для аналізу сучасного стану конфлікту інтересів. Моделювання та прогнозування - для розроблення пропозииій щчодо вдосконалення прочедури врегулювання конфлікту інтересів та запобігання йому.

Результати. Проаналізовано нормативно-правові акти національного й міжнародного законодавства, яке регламентує діяльність у напрямі врегулювання конфлікту інтересів та запобігання йому. 3'ясовано, щзо основним нормативним актом міжнародного права є Конвенція ООН проти корупиї 2003 року. У вітчизняному законодавстві поняття «конфлікт інтересів» уперше закріплене у 2011 роичі в Законі України «Про засади запобігання та протидії корупиії». Найчастіше його досліджують як елемент механізму недопущення зловживання державними повноваженнями або як принщип доброчесності державної влади. Визначено, щуо в національному законодавстві конфлікт інтересів поділяють на потенційний і реальний, у міжнародній законодавчій практиці-на очевидний та потенційний. Виокремлено основні ознаки та причини виникнення конфлікту інтересів як різновиду правопорушення, пов'язаного з корупцією. Констатовано, щзо конфлікт інтересів та корупиію не можна розглядати у прямому взаємозв 'язку.

Досліджено статистику Transparency International щзодо індексу сприйняття корупиії за 2020 рік та звіт Національного агентства з питань запобігання корупиії за 2020 рік, за результатами чого обгрунтовано, щзо в Україні, незважаючи на антикорупційну реформу, загальний рівень корупції залишається високим.

Теоретично обгрунтовано, щзо основним механізмом урегулювання конфлікту інтересів є його правове унормування на рівні закону. Окреслено основні напрями щзодо протидї конфлікту інтересів $і$ запобігання йому. Розглянуто позитивний досвід урегулювання конфлікту інтересів на державній служсі в Німеччині та Франиії, антикорупиійна політика яких спрямована здебільшого не на врегулювання конфлікту інтересів, а на запобігання його виникненню. Констатовано, щзо в міжнародній практиці виокремлюють три моделі врегулювання конфлікту інтересів: превентивну, модель «важкого шляху», compliance-based.

Висновки. Зроблено висновок, щзо забезпечувати протидію негативним проявам конфліктів інтересів можна лише иляхом визначення порядку дій державних службовиів, у яких він виник, та встановлення чіткого механізму врегулювання конфліктів. Надано пропозиції щодо внесення змін до Закону України «Про запобігання корупиї̈ та Кодексу України про адміністративні правопорушення.

Ключові слова: антикорупційна політика, нормативно-правові акти, міжнародна практика, державні повноваження, протидія конфлікту інтересів, механізм урегулювання. 